\title{
MONOSODIUM GLUTAMATE POTENTIATES THE CONTRACTION OF THE VISCERAL SMOOTH MUSCLE OF DUODENUM BY AUGMENTING THE ACTIVITY OF INTRINSIC CHOLINERGIC EFFERENTS, INDUCING OXIDATIVE STRESS AND PROLIFERATING SMOOTH MUSCLE CELLS
}

\author{
SURAIYA PARVIN, PARTHA PRATIM NATH, MOUSUMI DUTTA, MUKTI MONDAL, ASHMA KHATUN, \\ SANGHAMITRA PAL, MAHUA GUHA ROY, GOUTAM PAUL*
}

\author{
Department of Physiology, Molecular Neurotoxicology Laboratory, University of Kalyani, Kalyani, West Bengal, India. \\ Email: goutampaul.ku@gmail.com
}

Received: 02 April 2019, Revised and Accepted: 15 May 2019

\begin{abstract}
Objective: The objective of the present study was to examine the effects of monosodium glutamate (MSG) on the contraction of visceral smooth muscle (VSM) of the duodenum in a rat model to understand the MSG-induced impairment of the function of the small intestine.

Methods: Male albino rats of Charles Foster strain were exposed with MSG at three different dosages (632, 1264, and $2528 \mathrm{mg} / \mathrm{kg} \mathrm{BW} /$ day) for 30-day duration. The records of the contraction of the duodenum were achieved with isotonic transducer (IT-2245) coupled with RMS-Polyrite D by our standard laboratory protocol.

Results: We have observed potentiation of contraction of duodenum ex vivo dose-dependently in MSG exposed groups of rats compared to control. Furthermore, the enzymatic activity of acetylcholinesterase (AChE) in VSM tissue homogenate and expression of AChE protein in fixed duodenal muscle cell layers have been decreased in a dosage response manner comparing to control rats. We have found a significant decrease in the activities of some antioxidant enzymes such as $\mathrm{Cu}$-Zn superoxide dismutase, catalase, glutathione peroxidase, glutathione reductase, glutathione-s-transferase, and increase in the level of malondialdehyde in MSG exposed VSM tissue homogenate of the duodenum. We have also observed thickening of muscularis externa layer and increase in the number of muscle cells in circular and longitudinal muscle layers of the duodenal wall in transverse duodenal wall sections stained with eosin-hematoxylin.
\end{abstract}

Conclusion: MSG potentiates the contraction of VSM of duodenum by augmenting the activity of intrinsic cholinergic efferents predominantly, and inducing oxidative stress and proliferating smooth muscle cells.

Keywords: Monosodium glutamate, Duodenal movement, Acetylcholinesterase, Antioxidant enzymes, Oxidative stress, Muscularis externa layer.

(C) 2019 The Authors. Published by Innovare Academic Sciences Pvt Ltd. This is an open access article under the CC BY license (http://creativecommons. org/licenses/by/4. 0/) DOI: http://dx.doi.org/10.22159/ajpcr.2019.v12i7.33363.

\section{INTRODUCTION}

Monosodium glutamate (MSG), marketed as Ajinomoto, is one of the world's most extensively used taste enhancing food additive, which is ingested as part of commercially processed foods. Due to its salient umami taste, it is heedlessly used to prepare Chinese, Japanese and ready served foods such as 2-min noodles, soups, sauces, and chips. Although MSG improves taste sensation and enhances appetite, reports indicate that it is toxic to humans and experimental animals. The interest in the toxicity of MSG is being increased due to its association with Chinese restaurant syndrome [1-5]. According to Tawfik and AlBadr, alterations of the body weight and liver and kidney functions had been found when MSG is consumed at low dosage in rats [6]. Oladipo et al. observed MSG-induced considerable structural changes including degenerated follicles, oocytes, and medulla with vacuoles having congested blood vessels in the ovaries of Sprague-Dawley rats. Due to these reasons, female infertility may happen in case of the increased amount of consumption of MSG [7]. Igwebuike et al. revealed that MSG may provide adverse effects on spermatogenesis by disrupting hypothalamic-pituitary-testis regulatory axis [8]. Ajibola et al. suggested that MSG has significant effects on the platelet count, which may be an indicator of thrombocythemia conditions in the treated rats [9]. Iamsaard et al. observed some changes in the morphology of testis, testosterone level, and sperm concentration at a high dosage of MSG but the rate of acrosomal reaction was not affected significantly [10]. Mohamed IK reported that MSG produces deleterious effects on the spermatogenic cells in case of long-term daily exposure compared to short-term treatment. However, both short-term and long-term treatments may lead to infertility problem in experimental rats [11]. Our laboratory also reported that MSG impairs the contraction of uterine visceral smooth muscle (VSM) ex vivo of the rat through augmentation of acetylcholine and nitric oxide signaling pathways [12].

Toxic effects of MSG on the central nervous system, adipose tissue, hepatic tissue, and reproductive organs were shown in numerous animal studies. However, the reports about the probable toxic effects of MSG on the function of VSM found in the wall structure of the small intestine are still lacking.

The small intestine extends from the end of the stomach to the beginning of large intestine. It helps in the digestion and absorption of foodstuffs. In the stomach when food has become thoroughly mixed with the stomach secretions, the resulting mixture that passes down the gut is called chyme. During digestion, the chyme mixes with digestive juices secreted from intestinal exocrine glands by the movement of the intestine. The intestinal movement also helps in the absorption of digested foodstuffs and forward movement of the partially digested foodstuffs from the duodenum to ileum. The movement of the intestine is provided by the spontaneous rhythmic contraction of VSM found in the wall structure of the small intestine. As duodenum is the first part of the small intestine, digestion and absorption of most of the majority of ingested foodstuffs take place in this part. Hence, when we 
consume MSG added foods there is a possibility of the alterations in the movement of duodenum probably due to toxic effects of MSG on the contractile function of VSM of the duodenal wall structure [13]. Hence, the aim of the present study was to examine the probable toxic effects of MSG on the motor functions of VSM of the duodenum, as a representative structure of the small intestine in a rat model.

\section{METHODS}

Reagents/chemicals

All the reagents used were of analytical grade. MSG $(\leq 99 \%)$ was purchased from Sigma-Aldrich, USA. 5,5'-dithiobis-2-nitrobenzene (DTNB), oxidized and reduced glutathione, and nicotinamide adenine dinucleotide phosphate (NADPH.Na ${ }_{4}$ ) were procured from SRL Pvt., Ltd., India. $\mathrm{NaCl}$, trichloroacetic acid (TCA), tris, BSA, glacial Acetic acid, $\mathrm{NaOH}$, Triton-X-100, ethylenediaminetetraacetic acid (EDTA), CuSo, Folin and Ciocalteu's reagent, sodium potassium tartrate, pyrogallol, thiobarbituric acid (TBA), $\mathrm{HCl}, \mathrm{K}_{2} \mathrm{Cr}_{2} \mathrm{O}_{7}$ 1-chloro-2,4-dinitrobenzene (CDNB), $\mathrm{KH}_{2} \mathrm{PO}_{4}, \mathrm{~K}_{2} \mathrm{HPO}_{4}, \mathrm{Na}_{2} \mathrm{HPO}_{4}, \mathrm{NaH}_{2} \mathrm{PO}_{4}, \mathrm{H}_{2} \mathrm{O}_{2}$, sodium azide, acetylthiocholine iodide, etc., and sodium chloride, potassium chloride $(\mathrm{KCl})$, magnesium chloride $\left(\mathrm{MgCl}_{2}\right)$, calcium chloride $\left(\mathrm{CaCl}_{2}\right)$, sodium bicarbonate $\left(\mathrm{NaHCO}_{3}\right)$, sodium dihydrogen phosphate $\left(\mathrm{NaH}_{2} \mathrm{PO}_{4}\right)$, glucose, ethanol, eosin and hematoxylin, neutral red, silver nitrate, and sodium thiosulfate were procured from E. Merck, Mumbai, India.

\section{Animals}

Male albino rats of Charles Foster strain weighing about 110-120 g were used for this study. The animals were taken care of under suitable environmental condition, i.e., equal light-dark cycle (12L:12D) and room temperature of $25^{\circ} \mathrm{C} \pm 2^{\circ} \mathrm{C}$ and fed standard laboratory chow, water ad libitum. The animals were maintained in the animal house as per recommendations of the Kalyani University Animal Ethics Committee. The animals were sacrificed by cervical dislocation on the $24^{\text {th }} \mathrm{h}$ after the completion of the last treatment dosage.

\section{Experimental design}

After acclimatization of the experimental rats to the laboratory environment, the following experimental design has been set up for the chronic treatment of MSG for the duration of 30 days.

Graded percentages of $\mathrm{LD}_{50}$ value $(15,000-18,000 \mathrm{mg} / \mathrm{kg})$ of MSG have been selected according to the Joint FAO/WHO Expert Committee on Food Additives (JECFA), 1988 [14,15]. Dosages of MSG were administered by oral gavage mode (Table 1 ).

\section{Recording of contraction of the visceral smooth muscle of} duodenum

Segments of VSM of the duodenum were used for functional studies. After overnight fasting, each rat was sacrificed by cervical dislocation. The abdomen of the sacrificed rat was then opened immediately, and duodenal segments were collected by transverse incision. The segments of VSM of duodenum were placed in Tyrode solution containing $8.0 \mathrm{~g} / \mathrm{l}$ $\mathrm{NaCl}, 0.2 \mathrm{~g} / \mathrm{l} \mathrm{KCl}, 0.2 \mathrm{~g} / \mathrm{l} \mathrm{CaCl}, 0.1 \mathrm{~g} / \mathrm{l} \mathrm{MgCl}, 1.0 \mathrm{~g} / \mathrm{l} \mathrm{NaHCO}, 0.05 \mathrm{~g} / \mathrm{l}$ $\mathrm{NaH}_{2} \mathrm{PO}_{4}$, and $1.0 \mathrm{~g} / \mathrm{l}$ glucose ( $\left.\mathrm{pH} 7.4\right)$. A segment of duodenum $(2-3 \mathrm{~cm})$ was placed longitudinally in $50 \mathrm{ml}$ organ bath of Dale's apparatus continuously bubbled with $95 \% \mathrm{O}_{2}, 5 \% \mathrm{CO}_{2}$ maintaining a suitable environmental condition, i.e., temperature within a range of $37^{\circ} \mathrm{C} \pm 0.5^{\circ} \mathrm{C}$. The initial preparations were allowed to equilibrate for at least $40 \mathrm{~min}$

Table 1: Dosages of monosodium glutamate to the different groups of rats $(n=8)$

\section{Groups of animals Different dosages of MSG (percentage of} $\mathrm{LD}_{50}$ of MSG and g MSG/kg BW/day)

Group I (control) Only distilled water (no test element)

Group II (treated I) $\quad 4 \%$ of $\mathrm{LD}_{50}$ of MSG (0.632 g MSG/kg BW/day)

Group III (treated II) $\quad 8 \%$ of LD $_{50}$ of MSG (1.264 g MSG/kg BW/day)

Group IV (treated III) $16 \%$ of $\mathrm{LD}_{50}$ of MSG (2.528 g MSG/kg BW/day)

MSG: Monosodium glutamate, BW: Body weight by applying an initial load of $0.1 \mathrm{gm}$. During this period, the experimental preparations underwent repeated and continuous washes with Tyrode's solution to avoid the accumulation of metabolites in the organ bath. Continuous recording of duodenal movement was achieved with isotonic transducer (IT-2245) coupled with RMS-Polyrite D software (RMS, Chandigarh, India) by our standard laboratory protocol [16].

\section{Sample collection for enzymatic analysis and histological,} histochemical studies

After 30 days duration, the animals were sacrificed by cervical dislocation. Segments of VSM of the duodenum were collected, washed in ice-cold buffer solution, preserved in Eppendorf with the help of liquid nitrogen and finally stored in $-20^{\circ} \mathrm{C}$ for further analysis of enzymatic studies. The duodenal tissue was washed in buffer and preserved in neutral buffer formalin for further histological studies.

\section{Homogenate preparation of visceral smooth muscle tissue of the} duodenum

VSM tissue of the duodenum was weighted $0.2 \mathrm{gm}$. Then, the tissue was minced in a Petri plate in ice cold in $10 \mathrm{ml}$ of $0.1(\mathrm{M})$ phosphate buffer solution. Then, EDTA $(2 \mathrm{mM})$ and $50 \mu \mathrm{l}$ Triton-X-100 $(0.5 \%)$ were added to the minced tissue in the cup. Total homogenization was carried out for 5-6 s. Then, the cup was left undisturbed in ice to obtain the maximum volume of soup. After that, the homogenized sample was centrifuged at $8000 \mathrm{rpm}$ for $10 \mathrm{~min}$, and the supernatant was collected and re-centrifuged at $12,000 \mathrm{rpm}$ for 5/10 min. Finally, the supernatant was collected and stored in Eppendorf at $-20^{\circ} \mathrm{C}$ for further biochemical studies.

\section{Biochemical estimations}

Acetylcholinesterase enzyme assay

Acetylcholinesterase (AChE) enzyme activity of VSM of the duodenum was assayed by the method of Ellman et al., 1961, followed by Srikumar et al., 2004, with slight modifications. At first, $0.4 \mathrm{ml}$ tissue homogenate and $2.6 \mathrm{ml}$ phosphate-buffered saline (PBS) $(0.1 \mathrm{M}, \mathrm{pH}$ 8) were taken in a cuvette. Then, $20 \mu \mathrm{l}$ of acetylthiocholine iodide was added. Absorbance was recorded at 2 min interval for $10 \mathrm{~min}$ at $412 \mathrm{~nm}$ using an ultraviolet-visible (UV-VIS) spectrophotometer. The enzyme activity was expressed as $\mu$ moles of substrate hydrolyzed $/ \mathrm{min} / \mathrm{mg}$ protein [17].

\section{Determination of oxidative stress biomarker}

Degree of lipid peroxidation was measured as per the protocol of Devasagayam and Tarachand, 1987. The assay mixture contained TCA:TBA: $\mathrm{HCl}$ (1:2:1), $0.1 \mathrm{ml}$ tissue homogenate sample. After mixing well, the assay mixture was heated for $10 \mathrm{~min}$, cooled and centrifuged at $3000 \mathrm{rpm}$ for $10 \mathrm{~min}$. Finally, the changes of color of the mixture were measured at $535 \mathrm{~nm}$ using a UV/VIS spectrophotometer against a blank sample containing earlier mixture, but only $0.1 \mathrm{ml}$ of double distilled water was taken instead of sample. Marker of lipid peroxidation, i.e. the end product of lipid peroxidation, malondialdehyde (MDA) was calculated by measuring the absorbance of pink color at $535 \mathrm{~nm}$ using a molar coefficient of $1.56 \times 10^{5} \mathrm{~mole}^{-1} \mathrm{~cm}^{-1}$ and the level of MDA was expressed as $\mu$ moles/mg protein [18].

\section{Determination of the activities of antioxidant enzymes}

Copper-zinc superoxide dismutase (Cu-Zn SOD) activity was estimated by the method of Marklund and Marklund, 1974. To $20 \mu \mathrm{l}$ of the duodenal sample, $2 \mathrm{ml}$ of $50 \mathrm{mM}$ Tris- $\mathrm{HCl}$ buffer ( $\mathrm{pH} \mathrm{8.2)} \mathrm{and} 20 \mu \mathrm{l}$ of $10 \mathrm{mM}$ pyrogallol were added. The absorbance was recorded at $420 \mathrm{~nm}$ for $4 \mathrm{~min}$ in a UV/VIS spectrophotometer. One unit of enzyme activity is equal to $50 \%$ inhibition of the rate of auto-oxidation of pyrogallol as determined by changes in absorbance/min at $420 \mathrm{~nm}$. The enzyme activity was expressed as U/mg protein [19].

The activity of catalase (CAT) was measured as per the protocol of Sinha, 1972, with some modifications. Initially, $5 \mathrm{ml}$ of assay mixture

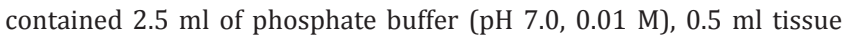
homogenate, $2 \mathrm{ml}$ of $0.2 \mathrm{M} \mathrm{H}_{2} \mathrm{O}_{2} 0.2 \mathrm{M}, \mathrm{V} / \mathrm{V}$ ). From this $5 \mathrm{ml}$ mixture, $1 \mathrm{ml}$ solution was taken in another test tube and $2 \mathrm{ml}$ of dichromateacetic reagent was added. The mixture was heated for $10 \mathrm{~min}$ and then 
cooled down. Finally, the color of the solution was measured at $570 \mathrm{~nm}$ against double distilled water. The enzyme activity was expressed as $\mu$ moles of hydrogen peroxide consumed $/ \mathrm{min} / \mathrm{mg}$ protein [20].

Glutathione reductase (GR) activity was measured according to the method of Staal et al., 1969, with slight modifications. The assay mixture of the final volume of $2.5 \mathrm{ml}$ contained $1.5 \mathrm{ml}$ of sodium phosphate buffer, $0.5 \mathrm{ml}$ of EDTA, $0.2 \mathrm{ml}$ of oxidized glutathione, and $0.1 \mathrm{ml}$ of NADPH. The blank was set with this mixture. The decrease in NADPH absorption was monitored spectrophotometrically at $340 \mathrm{~nm}$. The enzyme activity was expressed as $\mu$ moles of NADPH oxidized $/ \mathrm{min} / \mathrm{mg}$ protein $[21,22]$.

The activity of glutathione-s-transferase (GST) was determined by following the method of Habig et al., 1974. In the assay mixture, $0.4 \mathrm{ml}$ of buffer, $0.1 \mathrm{ml}$ of tissue homogenate, $1.2 \mathrm{ml}$ of water, and $0.1 \mathrm{ml}$ of CDNB were added and incubated in a water bath at $37^{\circ} \mathrm{C}$ for $10 \mathrm{~min}$. After incubation, $0.1 \mathrm{ml}$ of reduced glutathione was added and the absorbance was measured against double distilled water at $340 \mathrm{~nm}$ at $30 \mathrm{~s}$ interval for 4 min using a UV-VIS spectrophotometer. The enzyme activity was calculated as $\mu$ moles of CDNB-GSH complex formed $/ \mathrm{min} / \mathrm{mg}$ protein using a molar extinction coefficient of $9.6 \times 10^{3} \mathrm{M} / \mathrm{cm}$ [23]

The measurement of glutathione peroxidase (GPx) was performed following the method of Rotruck et al., 1973, with slight modifications. The assay system contained, in a final volume of $2 \mathrm{ml}, 0.5 \mathrm{ml}$ of phosphate buffer, $0.1 \mathrm{ml}$ of sodium azide, $0.2 \mathrm{ml}$ of reduced glutathione, $0.1 \mathrm{ml}$ of $\mathrm{H}_{2} \mathrm{O}_{2}, 0.5 \mathrm{ml}$ of tissue homogenate, and $0.6 \mathrm{ml}$ of double distilled water and incubated for $5 \mathrm{~min}$ at $37^{\circ} \mathrm{C}$. Then, $0.5 \mathrm{ml}$ of $10 \%$ TCA was added and centrifuged at $5000 \mathrm{rpm}$ for $5 \mathrm{~min}$. In the collected supernatant $2 \mathrm{ml}$ of $\mathrm{Na}_{2} \mathrm{HPO}_{4}, 0.5 \mathrm{ml}$ of DTNB were added. The absorbance was recorded against blank (Blank contain $1 \mathrm{ml}$ of $\mathrm{DH}_{2} \mathrm{O}, 2 \mathrm{ml}$ of $\mathrm{Na}_{2} \mathrm{HPO}_{4}$, and $0.5 \mathrm{ml}$ of DTNB) at $412 \mathrm{~nm}$ using a UV/VIS spectrophotometer. The specific activity was expressed as $\mu$ moles of GSH consumed/min $/ \mathrm{mg}$ protein $[24,25]$.

\section{Histochemical study}

Acetylcholinesterase staining process

To detect the deposition of aggregates of thiocholine iodide conjugate of AChE in VSM tissue of duodenum, the staining procedure followed by Filipe and Lake, 1983, was applied. The paraffin sections $(12 \mu \mathrm{M})$ were deparaffinized with xylene, rehydrated (graded percentages of ethanols). Then, sections were washed in PBS and placed in a incubating solution containing $5 \mathrm{mg}$ of acetylthiocholine iodide, $6.5 \mathrm{ml}$ of $0.1 \mathrm{M}$ acetate buffer ( $\mathrm{pH} 6.0), 0.5 \mathrm{ml}$ of $0.1 \mathrm{~m}$ sodium citrate $(2.94 \mathrm{~g} / 100 \mathrm{ml}), 1.0 \mathrm{ml}$ of $30 \mathrm{mM}$ copper sulphate $(0.58 \mathrm{~g} / 100 \mathrm{ml}), 1.0 \mathrm{ml}$ of distilled water, and $1.0 \mathrm{ml}$ of $5 \mathrm{Mm}$ potassium ferricyanide $(0.65 \mathrm{~g} / 100 \mathrm{ml})$ for overnight. Incubated sections were then rinsed with distilled water and stained with hematoxylin for $5 \mathrm{~min}$. The stained sections were then dehydrated and mounted with DPX. Stained sections finally were observed under the microscope $(\times 400)$. Images were obtained by digital SLR Olympus camera (E-620) fitted with Olympus light microscope (CH20i) [26].

\section{Histological study \\ Hematoxylin-eosin staining process}

Morphological changes of VSM tissue of duodenum were estimated following the method of Llewellyn BD with slight modifications. For this study, at first, paraffin impregnated slide sections $(5 \mu \mathrm{M})$ of duodenal tissue were deparaffinized with xylene and rehydrated through graded ethanol's. Then, the sections were stained with Harris hematoxylin for about $5 \mathrm{~min}$ and dipped into tap water to remove excess color. Colored sections after that were counterstained with the help of $1 \%$ eosin Y for about $10 \mathrm{~min}$ and then washed well with tap water. Finally, hematoxylineosin stained slides were dehydrated with alcohols, cleared with xylene, mounted with DPX. At last, the slides were observed under the microscope $(\times 100$ and $\times 400)$, and images were obtained by digital SLR Olympus Camera (E-620) fitted with an Olympus light microscope (CH20i) [27].

\section{Determination of protein}

The protein content was estimated following the protocol of Lowery et al., 1951, with bovine serum albumin as the standard [28].

\section{Statistical analysis}

All the data obtained from this study were expressed as Mean \pm SEM. Student's " $t$ " test was used for statistical analysis using the software GraphPad Prism 5.03 (Graph Pad software, Inc.).). $p<0.01$ and $p<0.001$ were considered as the level of significance for different types of experiments.

\section{RESULTS}

Effects of monosodium glutamate on the movement of duodenum ex vivo

We have observed a significant increase in the amplitude and frequency of the contraction of the duodenum in a dose-dependent manner recorded ex vivo in groups of rats exposed to different dosages of MSG for 30-day duration compared to control group of rats (Figs. 1 and 2).

Effects of monosodium glutamate on acetylcholinesterase enzyme activity of visceral smooth muscle of duodenum

A significant decrease in AChE enzyme activity in the VSM tissue homogenate was observed in the MSG exposed $\left(0.632,1.264\right.$, and 2.528 gm MSG kg $\left.{ }^{-1} \mathrm{BW}_{\text {day }}{ }^{-1}\right)$ groups of rats dosedependently compared to control group of rats (Fig. 3).

Effects of monosodium glutamate on acetylcholinesterase enzyme activity of visceral smooth muscle found in the wall structure of duodenum

We have found a significant decrease in the deposition of aggregates of the thiocholine iodide conjugate in the muscularis externa layer of the duodenal wall of the exposed groups of rats dose-dependently compared to a control group of rats. Arrowheads in figure indicate the size and location sites of the deposition of aggregates of thiocholine iodide conjugate in the muscularis externa layer as viewed under the microscope $(\times 400)$ (Fig. 4$)$.

\section{Effects of monosodium glutamate on malondialdehyde level}

Significant increase in the level of MDA, the marker of lipid peroxidation has been observed in MSG exposed groups of rats in a dose-response manner in comparison with control group of rats in VSM tissue homogenate of the duodenum ${ }^{* * *} \mathrm{p}<0.001$ versus control, $\mathrm{n}=8$ (Fig. $5 \mathrm{a}$ ).

Effects of monosodium glutamate on the activities of antioxidant enzymes

We have observed a significant decrease in the activities of antioxidant enzymes, namely Cu-Zn SOD, CAT, GR, GST, and GPx dose-dependently in MSG exposed groups of rats compared to control group of rats in duodenal smooth muscle tissue homogenate ${ }^{* * *} \mathrm{p}<0.001$ versus control, $n=8$ (Fig. 5b-f).

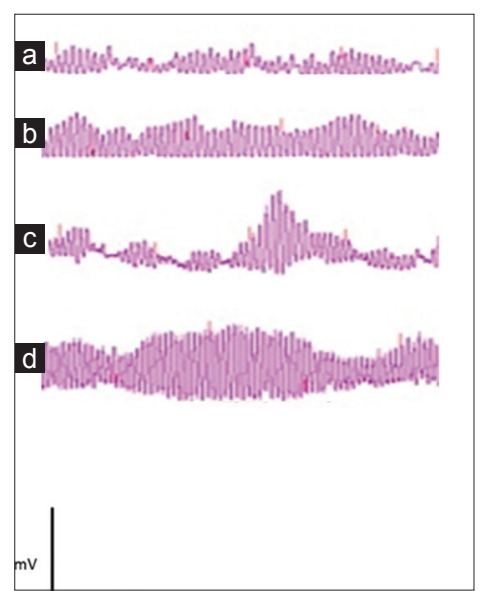

Fig. 1: Recording of the contraction of the duodenum of control and MSG exposed rats ex vivo: (a) Control group of rats; MSG exposed groups of rats: (b) Treated I group $\left(0.632 \mathrm{gm}\right.$ MSG $\mathrm{kg}^{-1}$ BW day ${ }^{-1}$ ), (c) Treated II group (1.264 gm MSG kg-1 BW day ${ }^{-1}$ ), (d) Treated III group (2.528 gm MSG kg-1 $\mathrm{BW} \mathrm{day}^{-1}$ ) 


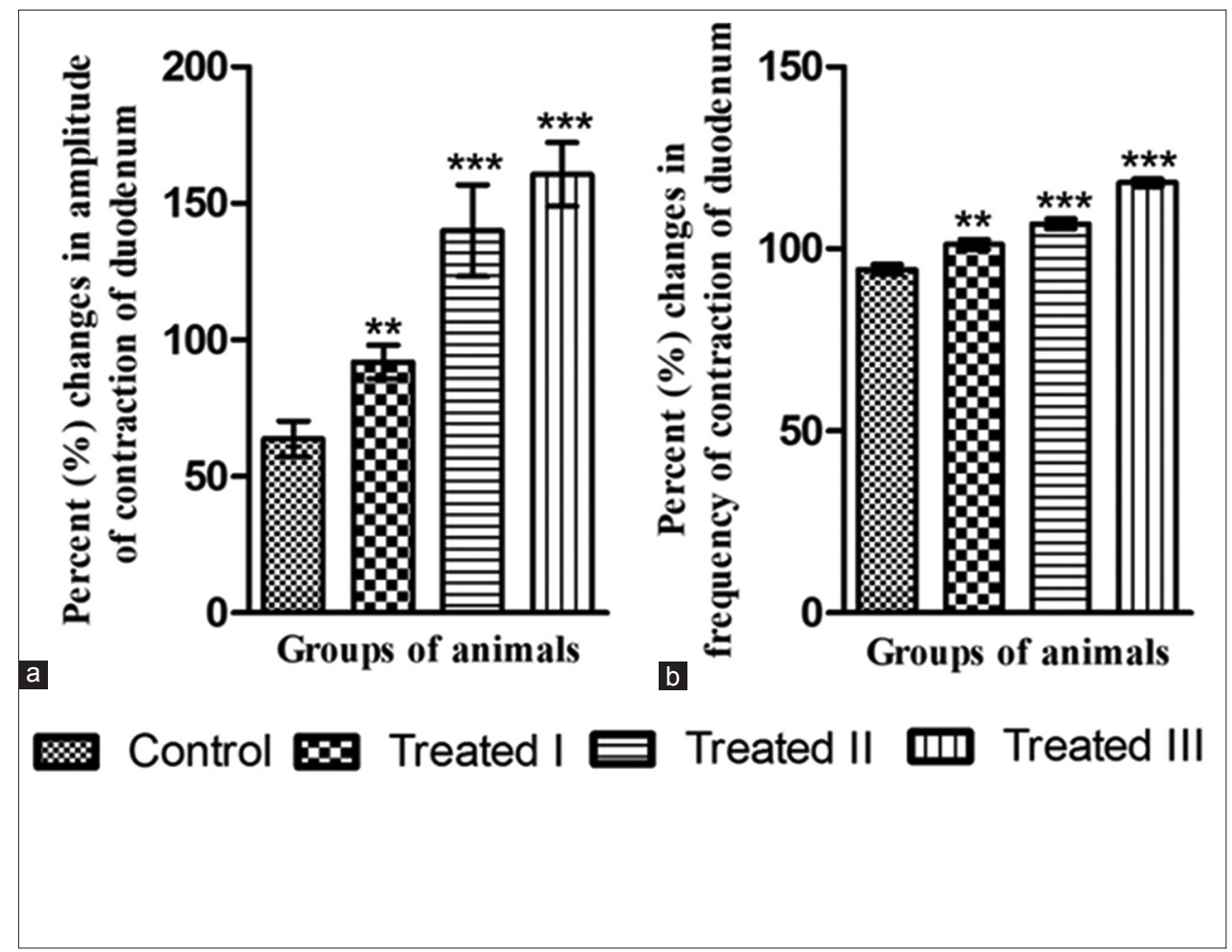

Fig. 2: Diagrammatic representations of the changes in amplitude (a) and frequency (b) of the contraction of the duodenum of a control group of rats and rats exposed to MSG at three different dosages $\left(0.632,1.264\right.$, and $\left.2.528 \mathrm{~g} \mathrm{MSG} \mathrm{kg}^{-1} \mathrm{BW} \mathrm{day}^{-1}\right)$ for duration of 30 days. Data are expressed as mean $\pm S E M . * * p<0.01$ versus control, ${ }^{* * *} \mathrm{p}<0.001$ versus control, $\mathrm{n}=8$

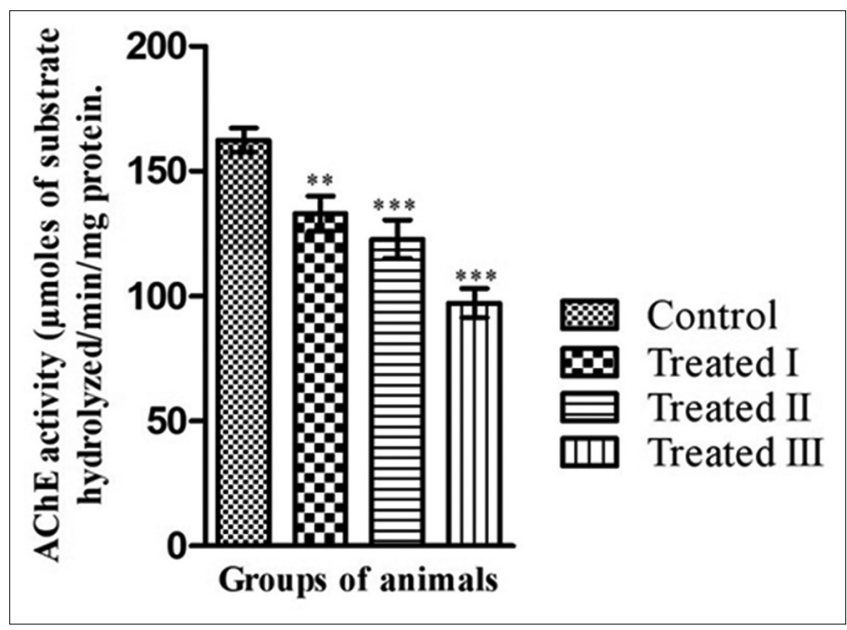

Fig. 3: Graphical representation showing the acetylcholinesterase enzyme activity in duodenal VSM of intestine of control group of rats and MSG exposed groups of rats: Treated I $\left(0.632 \mathrm{~g} \mathrm{MSG} \mathrm{kg}^{-1}\right.$ BW day $\left.{ }^{-1}\right)$, Treated II (1.264 $\left.\mathrm{g} \mathrm{MSG} \mathrm{kg}^{-1} \mathrm{BW} \mathrm{day}^{-1}\right)$, and Treated III (2.528 $\mathrm{g} \mathrm{MSG} \mathrm{kg}^{-1} \mathrm{BW}$ day $^{-1}$ ) groups of rats for 30 day duration. Values are expressed as mean \pm SEM. ${ }^{* *} \mathbf{p}<0.01$ versus control,

$* * * \mathbf{p}<0.001$ versus control, $(\mathrm{n}=\mathbf{8})$

Effects of monosodium glutamate on histoarchitectural changes of the smooth muscle layer in the wall structure of duodenum

We have found thickening of the muscularis externa layer in the wall structure of duodenum dose-dependently in MSG exposed groups of rats compared to the control group of rats. We have also observed a significant increase in the number of smooth muscle cells in a dose-response manner in inner circular and outer longitudinal smooth muscle layers of muscularis externa in MSG exposed groups of rats compared to the control group of rats as viewed in transverse sections

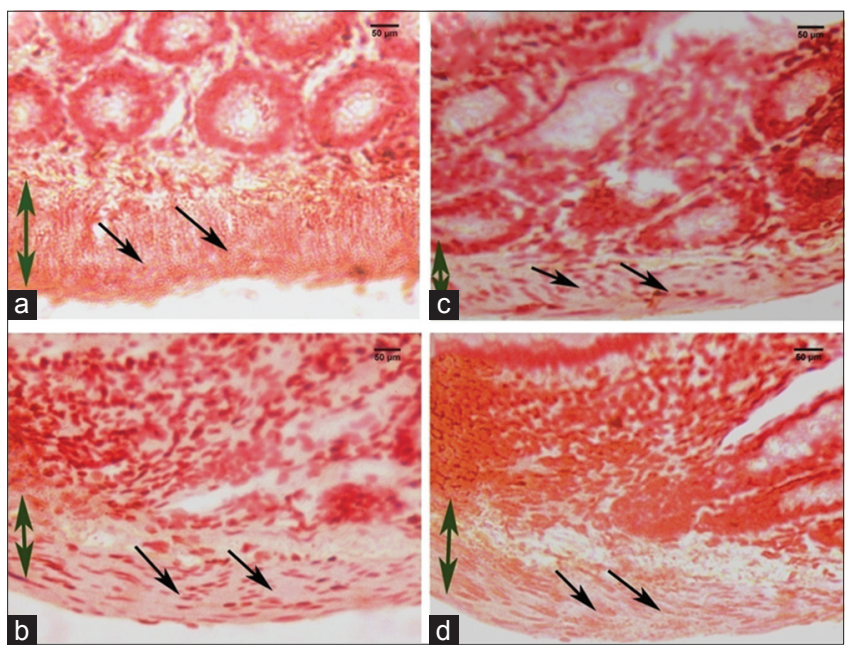

Fig. 4: Photomicrographs showing deposition of aggregates of thiocholine iodide conjugate in the muscularis externa layer of acetylcholinesterase stained transverse wall sections of the duodenum. Duodenal wall sections of (a) control group of rats, (b) MSG-treated Group I (0.632 $\left.\mathrm{g} \mathrm{MSG} \mathrm{kg}^{-1} \mathrm{BW} \mathrm{day}^{-1}\right)$, (c) MSGtreated Group II (1.264 $\mathrm{g} \mathrm{MSG} \mathrm{kg}^{-1} \mathrm{BW}$ day $^{-1}$ ), (d) MSG-treated Group III (2.528 g MSG kg-1 BW day $^{-1}$ ). Black colored arrowheads indicate deposition of aggregates of thiocholine iodide conjugate in the muscularis externa layer of VSM tissue of duodenum and green colored double arrowheads indicates muscularis externa layer of VSM tissue of duodenum. Images were captured $(\times 400)$ by digital SLR Olympus Camera (E-620) fitted with Olympus light microscope (CH20i)

of eosin and hematoxylin stained duodenum under the microscope $(\times 100$ and $\times 400)$ (Fig. 6a-d and a1-d1). 


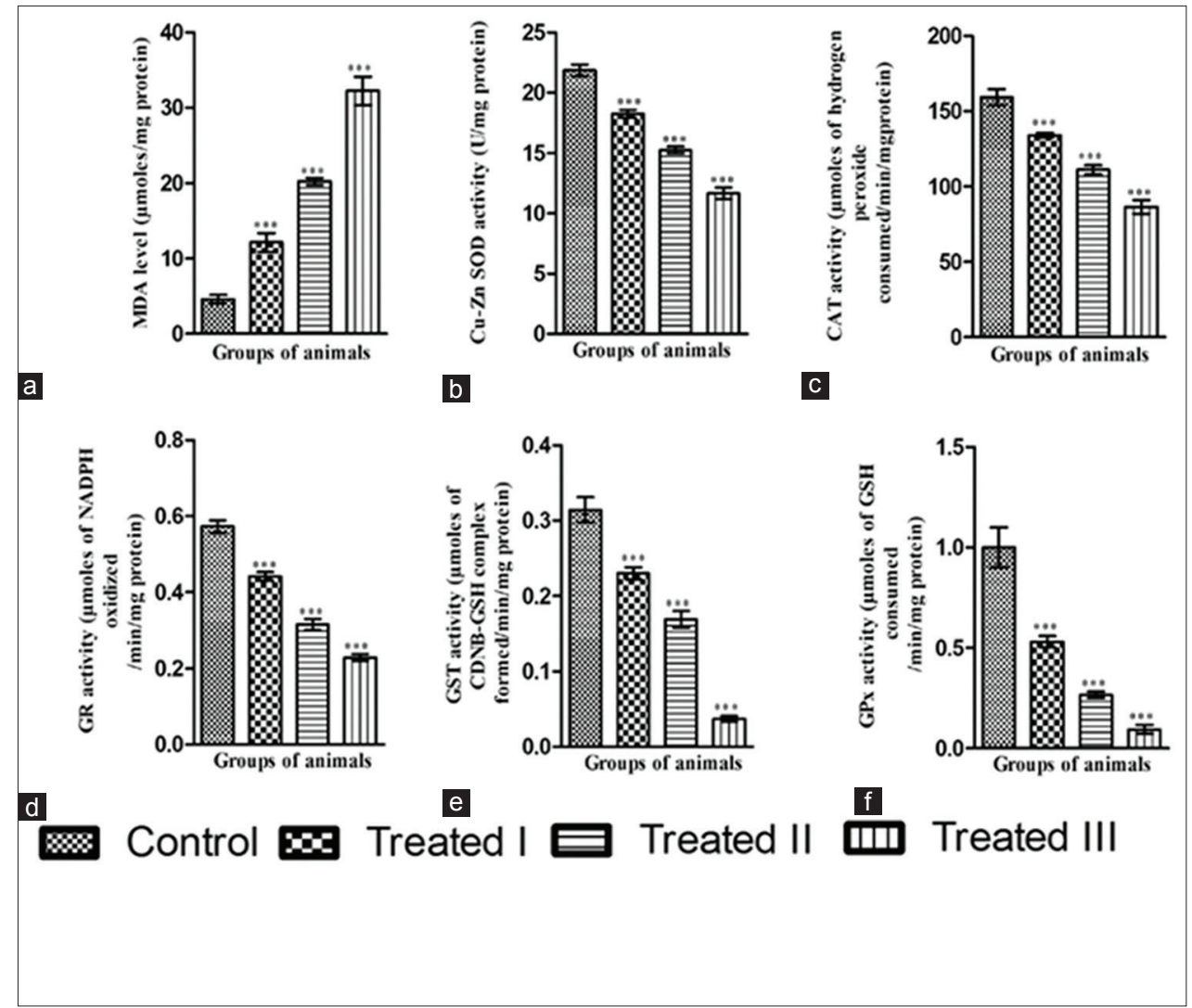

Fig.5: Graphical representations showing the (a) level of malondialdehyde (MDA) and activities of antioxidant enzymes: (b) superoxide dismutase (SOD), (c) catalase (CAT), (d)glutathione reductase (GR) (e) glutathione-s-transferase (GST), (f) glutathione peroxidase (GP X) in duodenal smooth muscle tissue homogenate of control and MSG exposed $\left(0.632,1.264,2.528 \mathrm{gm} \mathrm{MSG} \mathrm{Kg}^{-1} \mathrm{BW} \mathrm{day}^{-1}\right)$ groups of rats for a period of 30 days. Data are expressed as mean \pm sem $* * * p<0.001$ vs. control, $(\mathrm{n}=8)$

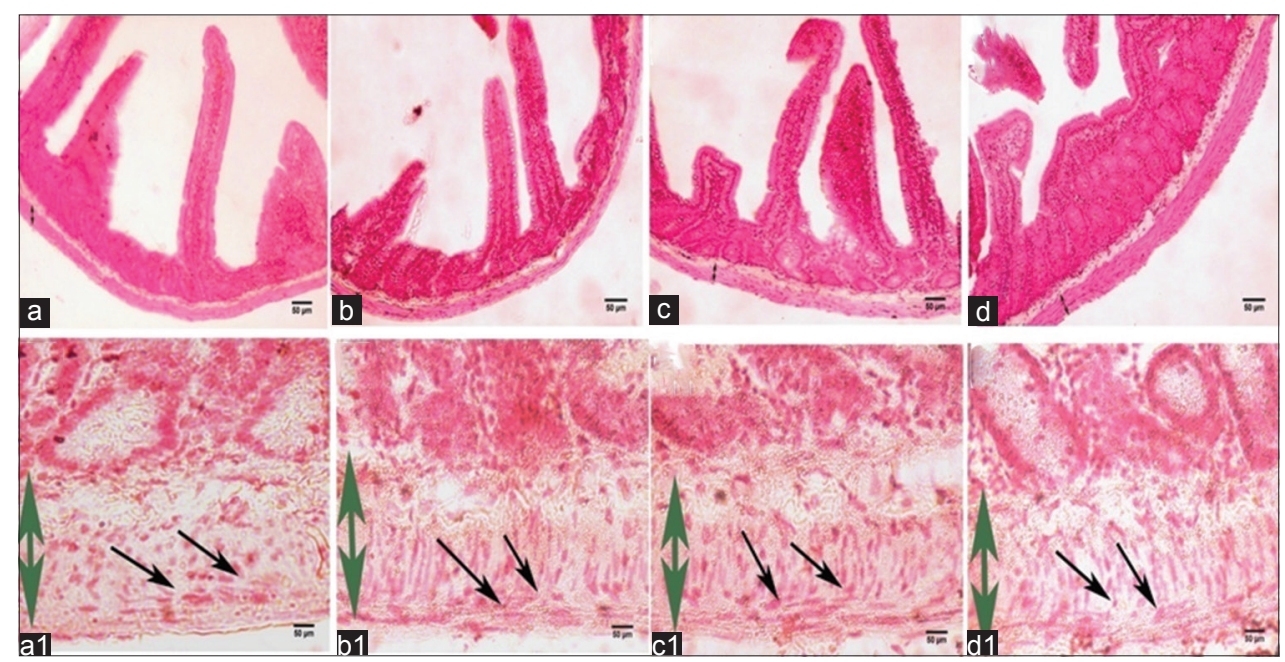

Fig. 6: Photomicrographs of representative eosin and hematoxylin stained duodenal wall transverse sections in control and MSG exposed groups of rats. Duodenal wall sections of a, a1: control group of rats, b, b1: MSG-treated Group I $\left(0.632 \mathrm{~g} \mathrm{MSG} \mathrm{kg}^{-1} \mathrm{BW} \mathrm{day} \mathrm{d}^{-1}\right)$, c, c1: MSG-treated Group II (1.264 g MSG kg-1 BW day $\left.{ }^{-1}\right)$, d, d1: MSG-treated Group III (2.528 $\left.\mathrm{g} \mathrm{MSG} \mathrm{kg}^{-1} \mathrm{BW} \mathrm{day}^{-1}\right)$. Green colored double arrowheads indicates thickening of the muscularis externa in exposed duodenal wall sections. Black colored arrowheads indicate a number of smooth muscle cells in circular and longitudinal muscle layers of muscularis externa. Images were captured (×100: a, b, c, d, and ×400: a1, b1, c1, d1) by digital SLR Olympus Camera (E-620) fitted with Olympus light microscope (CH20i)

\section{DISCUSSION}

Duodenum as a first part of the small intestine is exposed to MSG when MSG added foods are being consumed. Spontaneous movement of the duodenum allows the mixing of the foodstuffs with duodenal digestive juices for digestion and absorption of the majority of the digested end products in the duodenal lumen [29-31]. The VSM found in the muscularis externa layer of duodenal wall structure contributes to the movement of the duodenal wall during digestion and absorption of foods. MSG could exert either the facilitatory or the inhibitory effects on the contractile function of the VSM cells of duodenum probably by modulating the activity of intrinsic 
efferents innervating the smooth muscle and/by producing stress in the smooth muscle cells due to interference in the free radical scavenging mechanism. The objective of the present study was to understand the efferent neurocrine mechanism involved in the MSG-induced alterations in the contractile function of VSM of the duodenum; and the probable role of MSG in promoting oxidative stress in smooth muscle cells. We have found a significant increase in the amplitude and frequency of the contraction of the duodenum in a dose-dependent manner recorded ex vivo in groups of rats exposed to MSG for 30 days duration compared to control group of rats (Figs. 1 and 2). The results indicate that MSG potentiates the amplitude and frequency of the contraction of the duodenum probably by promoting the contraction of VSM of the duodenum. In the small intestinal intrinsic circuitry, cholinergic myenteric efferents facilitates the contraction of smooth muscle, and nor-adrenergic, and nitrergic myenteric efferents inhibit the contraction of the VSM. Hence, our results suggest that cholinergic myenteric efferents are probably involved in MSG-induced potentiation of the contraction of VSM of the duodenum.

To ascertain the involvement of myenteric cholinergic efferents in MSG-induced potentiation of the contraction of VSM of duodenum, the activity of AChE in VSM tissue homogenate of duodenum in MSG exposed groups of rats and control rats have been measured biochemically; and the expression of AChE enzyme in smooth muscle layers in the wall structure of duodenum has been detected histochemically. In our study, the activity of AChE enzyme in VSM tissue homogenate of the duodenum has been decreased dose-dependently in MSG exposed groups of rats compared to the control group of rats (Fig. 3). These results suggest that MSG facilitates the contraction of VSM of duodenum probably by augmenting the myenteric cholinergic efferents innervating the smooth muscle cells. The augmentation of the myenteric cholinergic efferents might be due to inhibition of the activity of AChE, the enzyme that splits acetylcholine into acetate and choline during neuromuscular transmission. Further, we have found a significant decrease in the deposition of aggregates of the thiocholine iodide conjugate in the muscularis externa layer of the duodenal wall of the MSG exposed groups of rats dose-dependently compared to control group of rats (Fig. 4a-d). We have used acetylthiocholine iodide as a substrate of AChE enzyme found intrinsically in the smooth muscle cells. AChE enzyme hydrolytically splits acetylthiocholine iodide into thiocholine and acetic acid, and as a result, thiocholine iodide conjugates are formed. Hence, the number of an aggregate of thiocholine iodide conjugate in the muscularis externa layer of duodenum indicates the degree of activity of AChE enzyme in the MSG exposed smooth muscle cells. Hence, our result indicates that MSG augments the myenteric cholinergic efferents probably by inhibiting the AChE enzyme activity in the smooth muscle synapse. The histochemical study of the activity of AChE enzyme substantiates the results about the activity of AChE enzyme obtained from the biochemical results.

We have examined the activities of some antioxidant enzymes and other oxidative stress indices in VSM tissue homogenate to understand the probable involvement of oxidative stress in VSM of the duodenum in MSG-induced potentiation of the contraction of VSM of the duodenum. In our study, we have observed a significant decrease in the activities of some antioxidant enzymes, namely Cu-Zn SOD, CAT, GR, GST, and GPx; and significant increase in the level of MDA and the marker of lipid peroxidation have been observed in MSG exposed groups of rats in a dose-response manner in comparison with control group of rats in duodenal smooth muscle tissue homogenate (Fig. 5). These results suggest that MSG partially potentiates the contraction of VSM of duodenum probably by inducing the oxidative stress in smooth muscle cells. The induction in oxidative stress might be due to the involvement of MSG in reducing the activities of antioxidant enzymes inside the smooth muscle cells.

Further, to examine the proliferative role of MSG in potentiating the contraction of VSM of the duodenum, the histology of the muscularis externa layer of the duodenum in MSG exposed and a control group of rats have been studied by standard eosin-hematoxylin staining technique. In our study, we have found thickening of the muscularis externa layer in the wall structure of duodenum dose-dependently in exposed groups of rats compared to control group of rats as viewed in transverse sections of eosin and hematoxylin stained duodenum under the microscope $(\times 100)$ (Fig. 6a-d). We also observed a significant increase in the number of smooth muscle cells in a dose-response manner in inner circular and outer longitudinal smooth muscle layers of muscularis externa in MSG exposed groups of rats compared to control group of rats $(\times 400)$ (Fig. 6a1-d1). Hence, the result indicates that MSG-induced potentiation of the contraction of VSM of the duodenum may partially be due to a proliferation of the smooth muscle cells and increase in the diameter of the muscularis externa in the wall structure of duodenum.

Considering the entire results of our study, we can conclude that MSG potentiates the contraction of VSM of duodenum predominantly by augmenting the activity of myenteric facilitatory cholinergic efferents innervating the circular and longitudinal smooth muscles in the muscularis externa layer; and partially by inducing the oxidative stress in the smooth muscle cells and promoting the proliferation of muscularis externa layer in the duodenal wall structure. MSG-induced augmentation of the activity of facilitatory myenteric cholinergic efferents might be due to prolongation of the action of acetylcholine secreted from the cholinergic efferents as a result of MSG-induced inhibition of AChE at synapse-en-passant structure. Thus, MSG impairs the function of duodenum probably by potentiating the movement of the wall of the duodenum

\section{CONCLUSION}

It can be concluded that MSG potentiates the movement of the duodenum probably by facilitating the contraction of VSM of duodenum found in the wall structure of duodenum. MSG-induced facilitation of contraction of VSM of duodenum predominantly might be due to augmentation of the activity of the myenteric facilitatory cholinergic efferents predominantly, and increase in oxidative stress in smooth muscle cells and proliferation of smooth muscle cells in the muscularis externa layer of the duodenum partially. Thus, holistically, MSG impairs the function of small intestine probably by potentiating the small intestinal wall movement.

\section{ACKNOWLEDGMENT}

The financial assistance of the Department of Higher Education, Government of West Bengal for research is gratefully acknowledged.

\section{AUTHORS' CONTRIBUTIONS}

SP: The main researcher, designing of problem, experimental study, manuscript preparation.

GP: Corresponding author, designing of the problem, manuscript preparation, manuscript correction.

PPN, MD, MM, AK, SP, MGR: Technical helper.

\section{CONFLICTS OF INTEREST}

The authors declare that there are no conflicts of interest. Neither this paper nor any part of it has been submitted for either in any journals or any other academic award elsewhere.

\section{REFERENCES}

1. Shubik P. Potential carcinogenicity of food additives and contaminants. Cancer Res 1975;35:3475-80.

2. Samuels A. The toxicity/safety of processed free glutamic acid (MSG): A study in suppression of information. Account Res 1999;6:259-310.

3. Jinap $\mathrm{S}$, Hajeb P. Glutamate. Its applications in food and contribution to health. Appetite 2010;55:1-0. 
4. Onakewhor JU, Oforofuo IA, Singh SP. Chronic administration of monosodium glutamate induces oligozoospermia and glycogen accumulation in Wister rat testes. Afr J Repord Health 1998;2:190-7.

5. Yamaguchi S, Ninomiya K. Umami and food palatability. J Nutr 2000;130:921S-6S

6. Tawfik MS, Al-Badr N. Adverse effects of monosodium glutamate on liver and kidney functions in adult rats and potential protective effect of Vitamins C and E. Food Nut Sci 2012;3:651-9.

7. Oladipo IC, Adebayo EA, Kuye OM. Effects of monosodium glutamate in ovaries of female sprague-dawley rats. Int J Curr Microbiol Appl Sci 2015;4:737-45

8. Igwebuike UM, Ochiogu IS, Ihedinihu BC, Ikokide JE, Idika IK. The effects of oral administration of monosodium glutamate (MSG) on the testicular morphology and cauda epididymal sperm reserves of young and adult male rats. Vet Arh 2011;81:525-34.

9. Ajibola M, Oloruntoba AC, Chinomso UA, Shekins O. The effects of orally administered monosodium glutamate (MSG) on blood thrombocyte, blood coagulation and bleeding in rats. IOSR J Pharm Biol Sci 2012;4:4-8.

10. Iamsaard S, Sukhorum W, Samrid R, Yimdee J, Kanla P, Chaisiwamongkol $\mathrm{K}$, et al. The sensitivity of male rat reproductive organs to monosodium glutamate. Acta Med Acad 2014;43:3-9.

11. Mohamed IK. The effects of oral dosage of monosodium glutamate applied for short and long terms on the histology and ultrastructure of testis of the adult rats. J Anim Vet Adv 2012;11:124-33.

12. Mondal M, Sarkar K, Nath PP, Khatun A, Pal S, Paul G, et al. Monosodium glutamate impairs the contraction of uterine visceral smooth muscle ex vivo of rat through augmentation of acetylcholine and nitric oxide signaling pathways. Reprod Biol 2018;18:83-93.

13. Gregersen H, Orvar K, Christensen J. Biomechanical properties of duodenal wall and duodenal tone during phase I and phase II of the MMC. Am J Physiol 1992;263:G795-801.

14. Walker R, Lupien JR. The safety evaluation of monosodium glutamate. J Nutr 2000;130:1049S-52.

15. FAO/WHO. Joint FAO/WHO Expert Committee on Food Additives (JECFA), L-glutamic Acid and its Ammonium, Calcium, Monosodium and Potassium Salts. Toxicological Evaluation of Certain Food Additives and Contaminants. New York: Cambridge University Press; 1988. p. 97-161.

16. Sarkar K, Tarafdar P, Partha NP, Paul G. Bisphenol a inhibits duodenal movement in rat by increasing acetylcholinesterase activity and decreasing availability of free calcium in smooth muscle cells. Int $\mathrm{J}$ Pharm Bio Sci 2013;4:679-88

17. Srikumar BN, Ramkumar K, Raju TR, Rao BS. Assay of acetyl cholinesterase activity in the brain. Brain Behav 2004;25:142-4.

18. Devasagayam TP, Tarachand U. Decreased lipid peroxidation in the rat kidney during gestation. Biochem Biophys Res Commun 1987; $145: 836-42$.

19. Marklund S, Marklund G. Involvement of the superoxide anion radical in the autoxidation of pyrogallol and a convenient assay for superoxide dismutase. Eur J Biochem 1974;47:469-74.

20. Sinha AK. Colorimetric assay of catalase. Anal Biochem 1972;47:389-94

21. Staal GE, Visser J, Veeger C. Purification and properties of glutathione reductase of human erythrocytes. Biochim Biophys Acta 1969;185:39-48.

22. Dutta M, Ghosh AK, Basu A, Bandyopadhyay D, Chattopadhyay A. Protective effect of aqueous bark extract of Terminalia arjuna against copperascorbate induced oxidative stress in vitro in goat heart mitochondria. Int J Pharm Pharm Sci 2013;5:439-47.

23. Habig WH, Pabst MJ, Jakoby WB. Glutathione S-transferases. The first enzymatic step in mercapturic acid formation. J Biol Chem 1974;249:7130-9.

24. Rotruck JT, Pope AL, Ganther HE, Swanson AB, Hafeman DG, Hoekstra WG, et al. Selenium: Biochemical role as a component of glutathione peroxidase. Science 1973;179:588-90.

25. Dutta M, Paul G. Bisphenol a dose and time-dependently induces oxidative stress in rat liver mitochondria ex vivo. Asian J Pharm Clin Res 2018;11:98-105.

26. Filipe MI, Lake BD. Histochemistry in Pathology 1983. $2^{\text {nd }}$ ed. Edinburgh: Churchill Livingstone; 1983.

27. Llewellyn BD. Nuclear staining with alum hematoxylin. Biotech Histochem 2009;84:159-77.

28. Lowry OH, Rosebrough NJ, Farr AL, Randall RJ. Protein measurement with the folin phenol reagent. J Biol Chem 1951;193:265-75.

29. Guyton AC, Hall JE. Textbook of Medical Physiology. $11^{\text {th }}$ ed. Philadelphia, PA: Saunders-Elsevier; 2006.

30. Ganong WF. Review of Medical Physiology. Lange Medical Books. $21^{\text {st }}$ ed. New York: McGraw Hill; 2003.

31. Hansen MB. Small intestinal manometry. Physiol Res 2002;51:541-56. 